\title{
Determination of air-loop volume and radon partition coefficient for measuring radon in water sample
}

\author{
Kil Yong Lee • William C. Burnett
}

Received: 14 February 2013/Published online: 21 May 2013

(C) The Author(s) 2013. This article is published with open access at Springerlink.com

\begin{abstract}
A simple method for the direct determination of the air-loop volume in a RAD7 system as well as the radon partition coefficient was developed allowing for an accurate measurement of the radon activity in any type of water. The air-loop volume may be measured directly using an external radon source and an empty bottle with a precisely measured volume. The partition coefficient and activity of radon in the water sample may then be determined via the RAD7 using the determined air-loop volume. Activity ratios instead of absolute activities were used to measure the air-loop volume and the radon partition coefficient. In order to verify this approach, we measured the radon partition coefficient in deionized water in the temperature range of $10-30{ }^{\circ} \mathrm{C}$ and compared the values to those calculated from the wellknown Weigel equation. The results were within $5 \%$ variance throughout the temperature range. We also applied the approach for measurement of the radon partition coefficient in synthetic saline water ( $0-75$ ppt salinity) as well as tap water. The radon activity of the tap water sample was determined by this method as well as the standard RAD$\mathrm{H}_{2} \mathrm{O}$ and BigBottle RAD- $\mathrm{H}_{2} \mathrm{O}$. The results have shown good agreement between this method and the standard methods.
\end{abstract}

\footnotetext{
K. Y. Lee $(\bowtie)$

Geologic Environment Division, Korea Institute of Geoscience and Mineral Resources, 124 Gwahang-no, Yuseong-gu,

Daejeon 305-350, Korea

e-mail: kylee@kigam.re.kr

W. C. Burnett

Department of Earth, Ocean and Atmospheric Science, Florida

State University, Tallahassee, FL 32306, USA
}

Keywords Water radon $\cdot$ Air-loop volume $\cdot$ Air-water partitioning $\cdot$ Temperature $\cdot$ Salinity $\cdot$ Radon partition coefficient

\section{Introduction}

Radon-222 (radon) is a member of the ${ }^{238} \mathrm{U}$ decay series and a radioactive inert gaseous nuclide. Exposure to radon gas is one of the greatest health concerns related to naturally occurring radioactivity. The principal health hazard associated with radon is due to its short-lived daughter products such as ${ }^{214} \mathrm{Po}$ and ${ }^{218} \mathrm{Po}$. The US Environmental Protection Agency (EPA) has estimated that 20,000 excess lung cancer deaths per year may be related to radon exposure. Overall, as a global average, at least $80 \%$ of the radon emitted into the atmosphere comes from the uppermost ground layer [1]. The second most important contributor to environmental radon is emanation from groundwater sources [2, 3]. On the other hand, radon has many useful geophysical applications and has been applied as a natural tracer in various fields of hydrology, geochemistry and oceanography. For example, research by many investigators has shown that radon can be a valuable tracer of direct groundwater discharge to the coastal ocean and other water bodies. Radon is an excellent tracer in these studies because it is: (1) often 3-4 orders of magnitude more concentrated in groundwater than typical surface waters, (2) completely conservative (inert), and (3) known to decay at a rate $\left(T_{1 / 2}=3.82 \mathrm{~d}\right)$ comparable to the time scale of circulation in many coastal settings $[4,5]$. Investigations to date have shown that radon is a very good tool for locating seeps, springs, and other points of discharge on the sea floor. Finding these points of discharge is an important first step, especially when contaminated groundwater may be involved. In addition, modeling approaches 
may be used to estimate quantitatively the volumes of groundwater actually being discharged if sufficient information concerning the radon concentration in the groundwater and other natural sources of radon is available for the study area $[5,6]$.

Several methods have been developed over the years to measure radon in water. Typical methods are gamma spectroscopy, scintillation (Lucas cells) and liquid scintillation counting (LSC). Gamma spectroscopy seeks to detect the gamma rays given off by radon's decay products from a closed container of radon-bearing water. The Lucas cell method tends to be somewhat labor intensive, using a complicated system of glassware and a vacuum pump to evacuate a Lucas cell, then bubble a carrier gas (usually helium) through the water sample until most of the radon has been transferred to the cells. In a typical LSC method, $12 \mathrm{~mL}$ of liquid scintillation cocktail is added to $8 \mathrm{~mL}$ water sample in a $20 \mathrm{~mL}$ counting vial. The cocktail extracts the radon out of the water, so that when it decays the alpha particles cause scintillation which is detected using phototube counting devices. The EPA has determined that the LSC method is as accurate as the Lucas cell approach, but less labor intensive, and less expensive [7]. LSC is also the standard American Society for Testing and Materials (ASTM) method for radon analysis in drinking water [8]. However, LSC counting is not typically sensitive enough for lower activity surface water analysis. Recent laboratory and field investigations have shown that radon in water may also be measured either in discrete water samples or in situ via alpha spectrometry by instruments such as the Durridge RAD7. The RAD7 is portable, durable, and very sensitive and operates in a continuous mode. A simple method for the continuous monitoring of radonin-water using a RAD7 coupled to an air-water exchanger was developed about 1 decade ago [4]. That system determines radon in continuously circulating air (in a closed air loop), which is in equilibrium with a constant stream of water passing through an air-water exchanger (commercialized as the RAD-AQUA). In that case, the concentration of radon in a water sample is calculated using the activity of radon in air, directly supplied by the RAD7, multiplied by the partition coefficient $(\mathrm{k})$ of radon between air and water $[4,9,10]$. Thus the radon $\mathrm{k}$, the activity ratio $\left(\mathrm{C}_{\mathrm{w}} / \mathrm{C}_{\mathrm{g}}\right)$ of radon in water $\left(\mathrm{C}_{\mathrm{w}}\right)$ to air $\left(\mathrm{C}_{\mathrm{g}}\right)$, must be known. In pure water, the standard Weigel equation can be used for the estimation of this coefficient [11]. Unfortunately, few data have been reported regarding the radon $\mathrm{k}$ in saline water until recently. This prompted many investigators to use the Weigel relationship even for seawater. A limited set of experimental data for the radon solubility in $\mathrm{NaCl}$ solutions was reported by Kofler in 1913 and republished by Clever after evaluation [12]. Recently, Schubert et al. [13] reported results of a series of laboratory experiments that describes the dependence of the partition coefficient upon both water temperature and salinity. RAD7 detectors and synthetic water having varying amounts of $\mathrm{NaCl}$ and sea salt were used in their investigation. Lee et al. [2, 3] have also reported the dependence of the radon $\mathrm{k}$ upon both temperature and groundwater impurities. They used LSC techniques and real groundwater samples in their work.

In order to make accurate measurements of the radon $\mathrm{k}$ value using a closed system RAD7 approach, it is necessary to have an accurately known volume of the air loop as well as the water volume. Thus, the first goal of this work was to develop a method for precisely measuring the air-loop volume of a RAD7 closed system used for determination of radon-in-water. Another goal was to establish a simple experimental process for the direct and simultaneous determination of the radon $\mathrm{k}$ and the radon activity of any water sample, no matter what salinity or composition. We present here a description of our approach for the determination of both the radon $\mathrm{k}$ and the radon activity in water by a new method with a simple design.

\section{Experimental}

\section{System}

The designed system consists of two closed air loops (A and B) as shown in Fig. 1. The closed air loop A (A-loop) includes a RAD7, a laboratory drying column (Drierite) and connection tubing up to the cutoff that separates the A-loop from the rest of the system $\left(\mathrm{V}_{\mathrm{t}}\right)$. The closed air loop B (B-loop) has a glass water bottle, and connection tubing with an aerator at the end. The radon source is a manganese dioxide impregnated acrylic fiber (Mn-fiber), charged with ${ }^{226} \mathrm{Ra}$ in a flow through column (Ra-column), with bypass valves so it can be separated from the closed air loops. The RAD7 has an approximately $0.9 \mathrm{~L}$ hemisphere internal sample cell, coated on the inside with an electrical conductor. A solid-state, ion-implanted, planar, silicon alpha detector is at the center of the hemisphere. The high voltage power circuit charges the inside conductor to a potential of 2000 to $2500 \mathrm{~V}$, relative to the detector, creating an electric field throughout the volume of the cell [7]. The electric field propels positively charged particles onto the detector. $\mathrm{A}{ }^{222} \mathrm{Rn}$ nucleus that decays within the dome leaves its transformed nucleus, ${ }^{218} \mathrm{Po}\left(\mathrm{t}_{1 / 2}=3.10 \mathrm{~min}\right.$; alpha energy $=6.00 \mathrm{MeV}$ ) as positively charged ions. The electric field attracts these positively charged ions to the detector, where they are measured. Energy discrimination allows one to select either or both the ${ }^{218} \mathrm{Po}$ or ${ }^{214} \mathrm{Po}$ windows for ${ }^{222} \mathrm{Rn}$ assessment. For faster analyses, the 
${ }^{218} \mathrm{Po}$ is preferred, as it will reach radioactive equilibrium with ${ }^{222} \mathrm{Rn}$ in only about $15 \mathrm{~min}$. The ${ }^{214} \mathrm{Po}$ lags behind because of the intermediate beta emitting daughters, ${ }^{214} \mathrm{~Pb}$ $\left(\mathrm{t}_{1 / 2}=27 \mathrm{~m}\right)$ and ${ }^{214} \mathrm{Bi}\left(\mathrm{t}_{1 / 2}=19.9 \mathrm{~m}\right)$ resulting in an equilibration time of approximately $3 \mathrm{~h}$.

Two RAD7 accessories for determination of radon activities in discrete water samples were used in this work, the "RAD- $\mathrm{H}_{2} \mathrm{O}$ " and "BigBottle $\mathrm{RAD}-\mathrm{H}_{2} \mathrm{O}$ ". The RAD- $\mathrm{H}_{2} \mathrm{O}$ has small glass bottles of $40 \mathrm{~mL}$ and $250 \mathrm{~mL}$ and a system for radon aeration from water samples to the closed air loop. In the BigBottle RAD- $\mathrm{H}_{2} \mathrm{O}, 2.5 \mathrm{~L}$ glass bottles are used instead of the small bottles in RAD- $\mathrm{H}_{2} \mathrm{O}$ for higher sensitivity. The water bottle used is a $2.5 \mathrm{~L}$ glass bottle with a specially designed closure having three ports that are connected to a temperature probe, an air inlet and outlet.

The connection tubing sets that we used were made of three thicknesses of Tygon tubing of $1 / 8^{\prime \prime}, 3 / 16^{\prime \prime}$ and $5 / 16^{\prime \prime}$ diameters. Vacuum grease was used at every connection, in order to minimize radon leakage in the closed air loops.

Figure 2 shows a flow chart for the determination of both the radon $\mathrm{k}$ and the radon activity in water samples used in this work. As shown in the figure, the volume of the air-loops is determined first by using an external $\mathrm{Rn}$ source. Next, the radon $\mathrm{k}$ is determined using one aliquot of the water sample itself. Finally, the radon activity in another portion of the same water sample is determined by applying the radon $\mathrm{k}$ and the determined radon activity in the air-loop, and the volumes of air-loops and water.

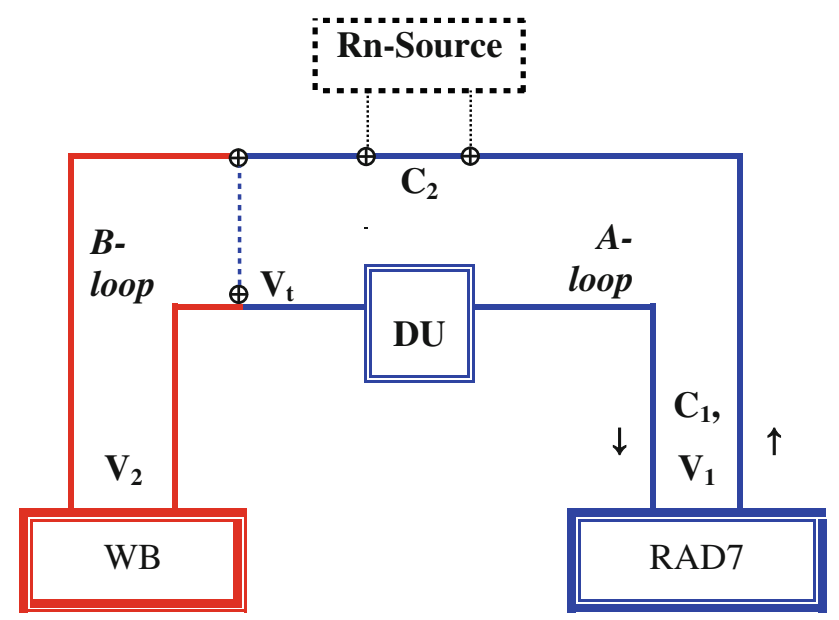

Fig. 1 Schematic diagram of the system designed in this work. WB, $2.5 \mathrm{~L}$ glass water bottle; DU, drying unit; RAD7, radon in air detector; A-loop, RAD7 and connection tubing set (blue line); B-loop, water bottle and connection tubing set (red line); $\mathrm{V}_{1}$ and $\mathrm{V}_{2}$, volume of A-loop and B-loop; $\mathrm{V}_{\mathrm{t}}$, volume of bypass tubing (dotted line); $\mathrm{C}_{1}$ and $\mathrm{C}_{2}$, radon activity concentration in A-loop and $\mathrm{A}+\mathrm{B}$-loops; $\oplus$, 2 -way valves. (Color figure online) (a)

(b)

(c)

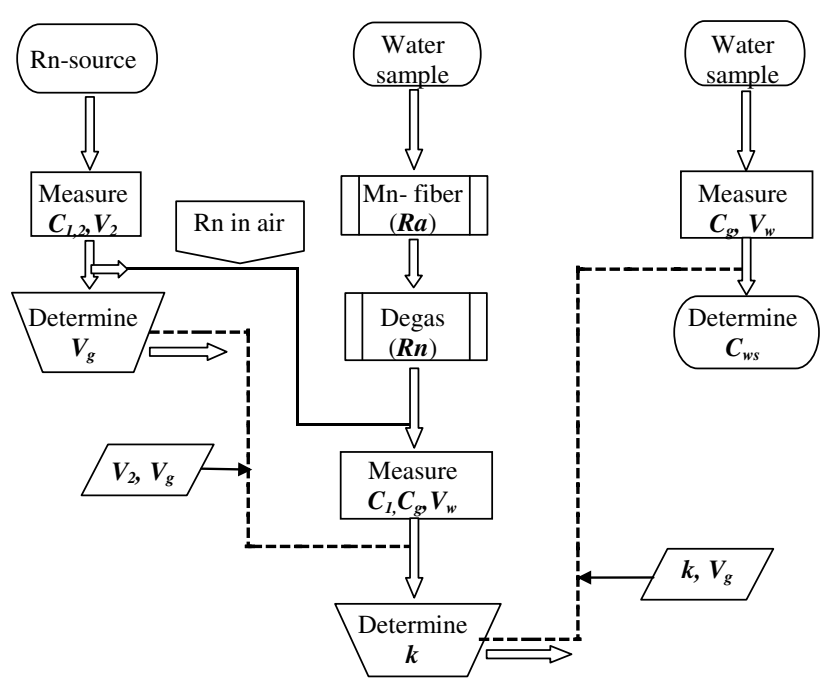

Fig. 2 Flow chart for the determination of radon activity of water used in this work. Three steps: (1) determination of the air volume of system $\left(\mathrm{V}_{1}, \mathrm{~V}_{2}, \mathrm{~V}_{\mathrm{t}}\right)$ : (a), (2) determination of the radon partition coefficient (k): (b), (3) determination of radon activity of the water sample $\left(\mathrm{C}_{\mathrm{ws}}\right):(\mathbf{c})$

Volume of the air-loops

The volume of the two closed air loops is measured by the following three steps. First, the volume of the B-loop $\left(\mathrm{V}_{2}\right)$ is measured by gravimetric means by filling the sample bottle with pure water and via calculation of the volume in the connection tubing set. Next, the radon is measured by the RAD7 in the A-loop $\left(\mathrm{C}_{1}\right)$ which includes the bypass tubing $\left(\mathrm{V}_{\mathrm{t}}\right)$ and then measured again after expanding to the $\mathrm{A}+\mathrm{B}-$ loop $\left(\mathrm{C}_{2}\right)$. Finally, the volume of the A-loop $\left(\mathrm{V}_{1}\right)$ is calculated using the known values for $\mathrm{V}_{2}, \mathrm{C}_{1}$ and $\mathrm{C}_{2}$. In the second step, the A-loop is filled with high radon air by connecting for a short time $(10 \mathrm{~min})$ to the Rn source and then $C_{1}$ is measured. After the B-loop is connected to the A-loop, $\mathrm{C}_{2}$ is measured. The RAD7 is running continuously during the second step. The volume of the A-loop $\left(\mathrm{V}_{1}\right)$ and $\mathrm{A}+\mathrm{B}$ loop $\left(\mathrm{V}_{1}+\mathrm{V}_{2}-\mathrm{V}_{\mathrm{t}}\right)$ can be calculated by a mass balance equation and the known values of $\mathrm{C}_{1}, \mathrm{C}_{2}$ and $\mathrm{V}_{2}$ as follows:

$\mathrm{C}_{1}\left(\mathrm{~V}_{1}-\mathrm{V}_{\mathrm{t}}\right)=\mathrm{C}_{2}\left(\mathrm{~V}_{1}+\mathrm{V}_{2}-\mathrm{V}_{\mathrm{t}}\right)$

$\mathrm{V}_{1}=\frac{\mathrm{C}_{2}\left(\mathrm{~V}_{2}-\mathrm{V}_{\mathrm{t}}\right)+\mathrm{C}_{1} \mathrm{~V}_{\mathrm{t}}}{\mathrm{C}_{1}-\mathrm{C}_{2}}$

where $\mathrm{V}_{1}, \mathrm{~V}_{2}$ are volume of the A- and B-loops. $\mathrm{V}_{\mathrm{t}}$ is the volume of the short tubing (dotted line in Fig. 1) that serves as a bypass so the air can only circulate through the A-loop or can be expanded to the entire system. $\mathrm{C}_{1}$ and $\mathrm{C}_{2}$ represent the radon activity in air of the A-loop and the $\mathrm{A}+\mathrm{B}$-loop, respectively. $V_{1}$ and $V_{2}$ will be used for determination of the radon $\mathrm{k}$ and radon in water (see next section). 
Radon partition coefficient

Deionized, tap water and artificial saline water samples were prepared to measure the radon $\mathrm{k}$. For removal of radon and radium from the water, $2 \mathrm{~L}$ of water were slowly passed through a Mn-fiber, and aerated with radon free compressed air using an air stone at a flow rate of $1 \mathrm{~L} / \mathrm{min}$ for $30 \mathrm{~min}$. Radon in the air loops with the deionized and tap water samples were less than $30 \mathrm{~Bq} / \mathrm{m}^{3}$, which is similar to the ambient background of the system. The radon $\mathrm{k}$ in the deionized water samples was measured at temperatures of 8.7, 18.3, 22.1 and $29.8^{\circ} \mathrm{C}$ and compared with those calculated from the standard Weigel equation. We prepared $1.5 \mathrm{~L}$ of cold deionized water samples $\left(8.7^{\circ} \mathrm{C}\right)$ by cooling in a refrigerator. Warm deionized water $\left(29.8^{\circ} \mathrm{C}\right)$ was prepared on a hot plate. Room temperature water was measured in the morning $\left(18.3^{\circ} \mathrm{C}\right)$ and afternoon $\left(22.1^{\circ} \mathrm{C}\right)$. Three saline water samples were made by dissolving artificial sea salt in radon free deionized water. The salinity, measured by conductivity, of the saline water samples were $19.5,38.5$ and $75.6 \%$. The radon $\mathrm{k}$ in the saline water samples was measured between 18.5 and $19.6{ }^{\circ} \mathrm{C}$ (average: $19^{\circ} \mathrm{C}$ ). The radon $\mathrm{k}$ in the tap water sample was measured at $19.8^{\circ} \mathrm{C}$. Before measuring the water temperature, the water bottle with a temperature probe is settled into an insulating box (an ice box) for $2 \mathrm{~h}$ for temperature stabilization. The A-loop was filled with high radon air from the $\mathrm{Rn}$ source for $10 \mathrm{~min}$. After closing the valves between the $\mathrm{Rn}$ source column and the A-loop, $\mathrm{C}_{1}$ is measured by circulating air through the A-loop which includes the RAD7. Then the bypass to the B-loop is opened and $\mathrm{C}_{2}$ is measured by the RAD7. The radon $\mathrm{k}$ in the tap water sample, deionized and saline water samples is then estimated by the respective air and water volumes and the radon activity of the air loops. Thus the radon activity in actual water samples, of any composition, can be determined by assessment of the radon $\mathrm{k}$ and the radon activity in air.

\section{Radon in tap water sample}

The radon activity in the tap water sample was determined by this method as well as established methods using the RAD- $\mathrm{H}_{2} \mathrm{O}$ and BigBottle RAD- $\mathrm{H}_{2} \mathrm{O}$. After the tap water was running continuously for $30 \mathrm{~min}$, we filled a $20-\mathrm{L}$ reservoir with water from the tap. Three water bottles were then filled simultaneously without any air bubbles by submerging the bottles into the water: a $2.5 \mathrm{~L}$ bottle for this method, a $250 \mathrm{~mL}$ bottle for the RAD- $\mathrm{H}_{2} \mathrm{O}$ and another $2.5 \mathrm{~L}$ bottle for the BigBottle RAD- $\mathrm{H}_{2} \mathrm{O}$ method. Each water bottle was closed under the water surface to prevent air from entering the bottles. The radon $\mathrm{k}$ and radon-in-air was measured by RAD7. And the radon activity of the tap water was calculated using these parameters as described above. The radon-in-water for the $\mathrm{RAD}-\mathrm{H}_{2} \mathrm{O}$ and BigBottle $\mathrm{RAD}-\mathrm{H}_{2} \mathrm{O}$ samples were determined as described in the Durridge manuals.

\section{Results and discussion}

Equilibrium conditions and leakage of the system

The equilibrium time for radon activity to stabilize in the air loop depends on the system characteristics such as the volume of the air loop, flow rate of air, system geometry, etc. Furthermore, if any leakage is present in the system, equilibrium may not be obtained or will be established at a lower value. Leakage of the system was measured by continuously running the RAD7 system for $24 \mathrm{~h}$. We observed a leakage rate of $8.5 \%$ for the A-loop and $9.5 \%$ for the A + B-loop over this period, a little larger than the $5 \%$ leakage rate reported by $\mathrm{Xu}$ et al. [14]. The leakage is thought to occur from the internal air pump in the RAD7 although some leakage from other parts of the system is certainly possible. However, the leakage rate of the system is less than $1 \%$ in both of the two closed air loops for the 2-h experimental period used for our experiments. Thus, the leakage can be neglected under these experimental conditions. The equilibrium time of radon in the system was investigated using the $\mathrm{Rn}$ source. Opening the connection between $\mathrm{Rn}$ source and the A-loop for $10 \mathrm{~min}$ resulted in an activity in the A-loop higher than $100,000 \mathrm{~Bq} / \mathrm{m}^{3}$ depending upon the ingrowth time of the radon in the source column. After the source is disconnected from the A-loop, radon in A-loop $\left(C_{1}\right)$ was measured for $60 \mathrm{~min}$. Finally, the B-loop is connected to the A-loop and radon in the $A+B-l o o p\left(C_{2}\right)$ was measured for an additional $60 \mathrm{~min}$. As shown in Fig. 3, the equilibration times for radon in the A-loop and the $\mathrm{A}+\mathrm{B}$-loop were around $20 \mathrm{~min}$.

Partition coefficient $(\mathrm{k})$ and activity of radon in water samples

The volume of the air loops $\left(\mathrm{V}_{1}\right.$ and $\left.\mathrm{V}_{2}\right)$ and the radon activity in each air loop $\left(\mathrm{C}_{1}\right.$ and $\left.\mathrm{C}_{2}\right)$ were obtained as described in the experimental section. Using these data, the radon $\mathrm{k}$ can be estimated by the following:

$\mathrm{C}_{1}\left(\mathrm{~V}_{1}-\mathrm{V}_{\mathrm{t}}\right)=\mathrm{C}_{\mathrm{we}} \mathrm{V}_{\mathrm{w}}+\mathrm{C}_{2} \mathrm{~V}_{\mathrm{g}}$

$\mathrm{k}=\frac{\mathrm{C}_{1}\left(\mathrm{~V}_{1}-\mathrm{V}_{\mathrm{t}}\right)}{\mathrm{C}_{2} \mathrm{~V}_{\mathrm{w}}}-\frac{\mathrm{V}_{\mathrm{g}}}{\mathrm{V}_{\mathrm{w}}}$

where $\mathrm{C}_{1}$ and $\mathrm{C}_{2}$ are the same as in Eq. (2), $\mathrm{C}_{\mathrm{we}}$ is the radon activity in water (originally radon free) at equilibrium, and $\mathrm{V}_{\mathrm{g}}\left(\mathrm{V}_{1}+\mathrm{V}_{2}-\mathrm{V}_{\mathrm{t}}-\mathrm{V}_{\mathrm{w}}\right)$ and $\mathrm{V}_{\mathrm{w}}$ are the total air and water volumes of the $\mathrm{A}+\mathrm{B}-\mathrm{loop}$, respectively. Using this approach, the radon $\mathrm{k}$ of 


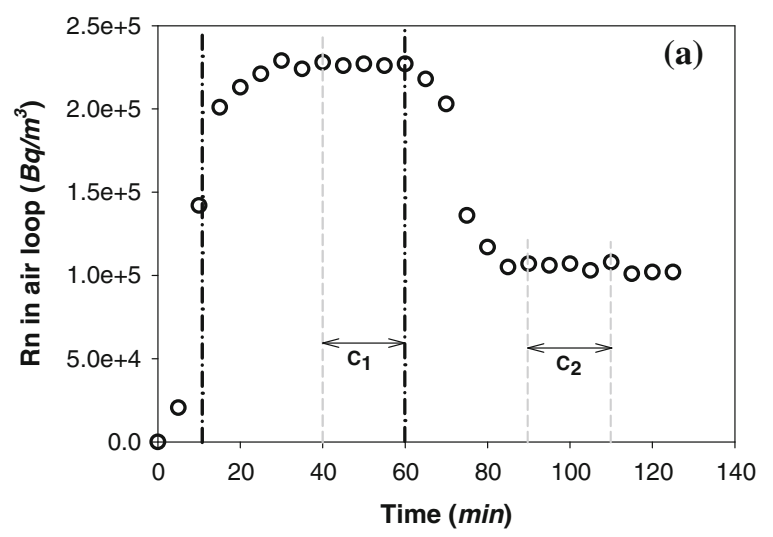

Fig. 3 Equilibrium time for radon between A-loop and B-loop without (a) and with (b) water in the water bottle. The radon source was connected to the loop-A at time 0 and disconnected after $10 \mathrm{~min}$. Radon in A-loop $\left(C_{l}\right)$ was measured from 40 to $60 \mathrm{~min}$, and the

deionized water, 3 saline water samples and a laboratory tap water was measured and the deionized water and tap water sample results were compared with Weigel's value (Fig. 4). The radon $\mathrm{k}$ in radon free deionized water showed good comparison to the values calculated by Weigel equation in the temperature range of $9-30{ }^{\circ} \mathrm{C}$. It was found that the radon $\mathrm{k}$ observed here was within the experimental uncertainty of those calculated from the Weigel equation. The radon $\mathrm{k}$ for pure water and in the 3 saline water samples were determined to be $0.258\left(18.9^{\circ} \mathrm{C}\right), 0.237$, 0.221 and 0.185 for $0.0,19.5,38.5$ and $75.6 \%$, respectively (Fig. 5). The radon $\mathrm{k}$ values obtained from this work were within the estimated uncertainty of those obtained from Schubert et al.'s experiment [12]. The radon $\mathrm{k}$ in the tap water was determined to be 0.238 , about $6.7 \%$ different, but within the statistical error than predicted by the Weigel equation. The radon activity of the tap water $\left(\mathrm{C}_{\mathrm{ws}}\right)$ can be calculated by mass balance and the experimental data shown above as follows:

$$
\begin{aligned}
& \mathrm{C}_{\mathrm{ws}} \mathrm{V}_{\mathrm{w}}=\mathrm{C}_{\mathrm{we}} \mathrm{V}_{\mathrm{w}}+\mathrm{C}_{\mathrm{g}} \mathrm{V}_{\mathrm{g}}=\mathrm{kC}_{\mathrm{g}} \mathrm{V}_{\mathrm{w}}+\mathrm{C}_{\mathrm{g}} \mathrm{V}_{\mathrm{g}} \\
& \mathrm{C}_{\mathrm{ws}}=\mathrm{C}_{\mathrm{g}}\left(\mathrm{k}+\frac{\mathrm{V}_{\mathrm{g}}}{\mathrm{V}_{\mathrm{w}}}\right)
\end{aligned}
$$

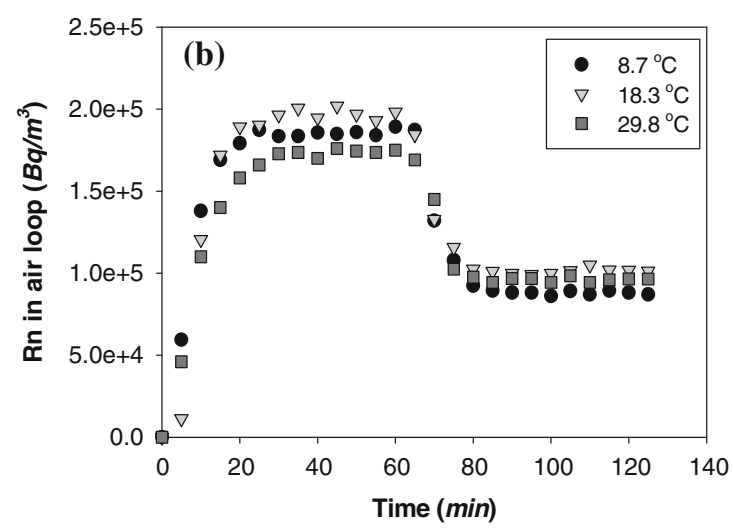

A-loop was connected to the B-loop at the 60 -min point. Radon in $\mathrm{A}+\mathrm{B}$-loop $\left(C_{2}\right)$ was then measured from 90 to $110 \mathrm{~min}$. The radon in A-loop $\left(C_{l}\right)$ was different from each other, because radon activity depends on equilibrium periods of Rn-source (Mn-fiber in Fig. 2)

where, $\mathrm{C}_{\mathrm{ws}}$ and $\mathrm{C}_{\mathrm{we}}$ are the original and equilibration radon activity of the tap water, $\mathrm{C}_{\mathrm{g}}$ is the radon activity in the air loops, $\mathrm{V}_{\mathrm{w}}$ and $\mathrm{V}_{\mathrm{g}}$ are the volumes of the water samples and the total air volumes of the A + B-loop, respectively. The determination of the radon activity in the tap water by the RAD- $\mathrm{H}_{2} \mathrm{O}$, BigBottle RAD- $\mathrm{H}_{2} \mathrm{O}$ and our method are shown in Table 1. Our result is within $5 \%$ uncertainty with the others. As can be seen in the table, the radon $\mathrm{k}$ from the standard Weigel equation is $0.255\left(19.8^{\circ} \mathrm{C}\right)$ while the radon $\mathrm{k}$ determined here is 0.238 . Hence, the results from two conventional methods, applying the Weigel $\mathrm{k}$ value, could overestimate $(6.7 \%)$ the true result because of the higher $\mathrm{k}$. It may be that the tap water has some impurities that may have affected the partition coefficient.

Effects of water volume on radon activity and partition coefficient

According to Eqs. (5) and (6), the radon activity in water samples $\left(\mathrm{C}_{\mathrm{ws}}\right)$ may be calculated using four parameters including the radon activity in the air loop $\left(\mathrm{C}_{\mathrm{g}}\right)$, radon partition coefficient $(\mathrm{k})$, and the volumes of the air loops
Fig. 4 Radon partitioning in radon free deionized and tap water by temperature (left) and the ratio of values determined experimentally to those calculated by Weigel's equation
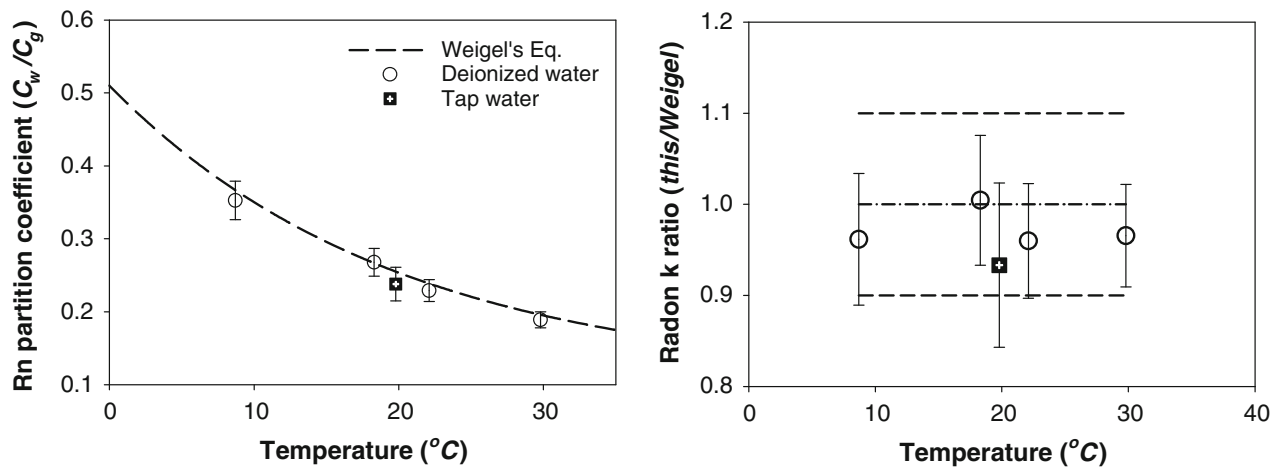


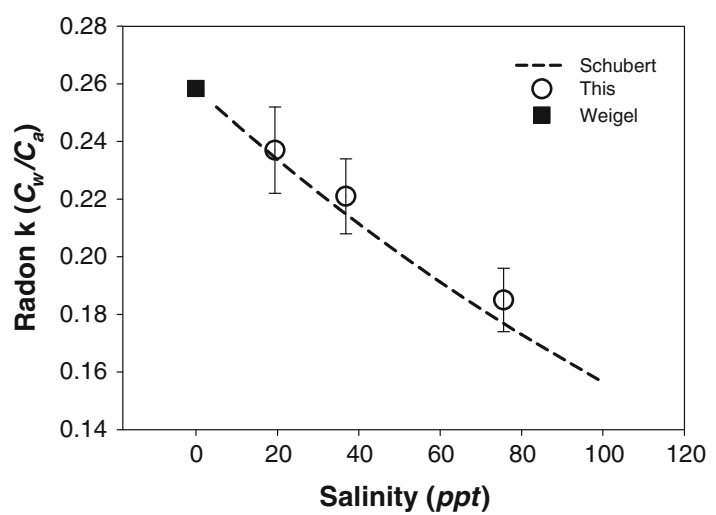

Fig. 5 Effects of salinity on the radon partition coefficient at $19{ }^{\circ} \mathrm{C}$. Schubert: values calculated from Schubert et al.'s [13] model equation, Weigel: value calculated from Weigel's [11] equation for pure water

Table 1 Radon activity and partition coefficients of the tap water sample

\begin{tabular}{lll}
\hline Method & $\mathrm{C}_{\mathrm{ws}}, \mathrm{Bq} / \mathrm{m}^{3}$ & $\mathrm{k}\left(19.8^{\circ} \mathrm{C}\right)$ \\
\hline BigBottle RAD- $\mathrm{H}_{2} \mathrm{O}$ & $7,630 \pm 990$ & $0.255^{\mathrm{a}}$ \\
RAD- $\mathrm{H}_{2} \mathrm{O}$ & $7,560 \pm 1,270$ & $0.255^{\mathrm{a}}$ \\
This work & $7,360 \pm 1,100$ & $0.238 \pm 0.022^{\mathrm{b}}$
\end{tabular}

Errors: $\mathrm{RAD}-\mathrm{H}_{2} \mathrm{O}$ : counting statistics

This work: error propagated from the counting statics of $\mathrm{C}_{1}$ and $\mathrm{C}_{2}$ in $\mathrm{k}$ calculation

$\mathrm{C}_{\mathrm{ws}}$, radon activity of the tap water; $\mathrm{k}$, radon partition coefficient

a Value calculated by Weigel's equation

b Value calculated from this work

$\left(\mathrm{V}_{\mathrm{g}}\right)$ and water $\left(\mathrm{V}_{\mathrm{w}}\right)$. Of these four, $\mathrm{C}_{\mathrm{g}}$ and $\mathrm{k}$ are not variable parameters in the system and because the total volume of the system is fixed, $V_{w}$ is the only variable easily controlled by the user. We investigated the effects of $V_{w}$ on the $\mathrm{C}_{\mathrm{g}}$ and the $\mathrm{k}+\mathrm{V}_{\mathrm{g}} / \mathrm{V}_{\mathrm{w}}$ term (Eq. 6) in the temperature range of $5-30{ }^{\circ} \mathrm{C}$ (Fig. 6). $\mathrm{C}_{\mathrm{g}}$, which is basically the "response" of the system (what the RAD7 is seeing), increases with increasing $\mathrm{V}_{\mathrm{w}}$ because there is more total radon in the system. On the other hand, the $\mathrm{k}+\mathrm{V}_{\mathrm{g}} / \mathrm{V}_{\mathrm{w}}$ term decreases with increasing water volume. The plots also show that the temperature effects on both $C_{g}$ and $\mathrm{k}+\mathrm{V}_{\mathrm{g}} / \mathrm{V}_{\mathrm{w}}$ terms increase with increasing $\mathrm{V}_{\mathrm{w}}$. This illustrates why the temperature measurement (and $\mathrm{k}$ term) is much more important when running discrete water samples at larger volumes in a closed system. Thus, temperature measurements are unimportant for small volumes (e.g., 40 and $250 \mathrm{~mL}$ RAD- $\mathrm{H}_{2} \mathrm{O}$ ) while they must be applied for larger volumes as the $2.5 \mathrm{~L}$ BigBottle RAD $-\mathrm{H}_{2} \mathrm{O}$ and the system designed here.

\section{Conclusions}

We have developed a simple method for the direct determination of the air-loop volume of a radon-in-air detector system which is being used for determination of radon-inwater in discrete water samples. Because the ratios of the air-loop volume $\left(\mathrm{V}_{\mathrm{g} 1} / \mathrm{V}_{\mathrm{g} 2}\right)$ and activities within different parts of the air-loop $\left(C_{1} / C_{2}\right)$ are used in this method, the air-loop volume of radon-in-air detector system must be determined accurately. The radon partition coefficient was determined using the ratio $\left(\mathrm{V}_{\mathrm{g}} / \mathrm{V}_{\mathrm{w}}\right)$ of the air-loop and water volume, and the activity ratio $\left(\mathrm{C}_{1} / \mathrm{C}_{2}\right)$ of the two airloops. Hence, the radon partition coefficient may be determined directly by this approach. The radon activity in water samples can also be determined using the derived radon partition coefficient and the radon activity in the airloop. The method developed here can thus be used for the direct determination of the radon activity in any water samples regardless of salinity and impurities.
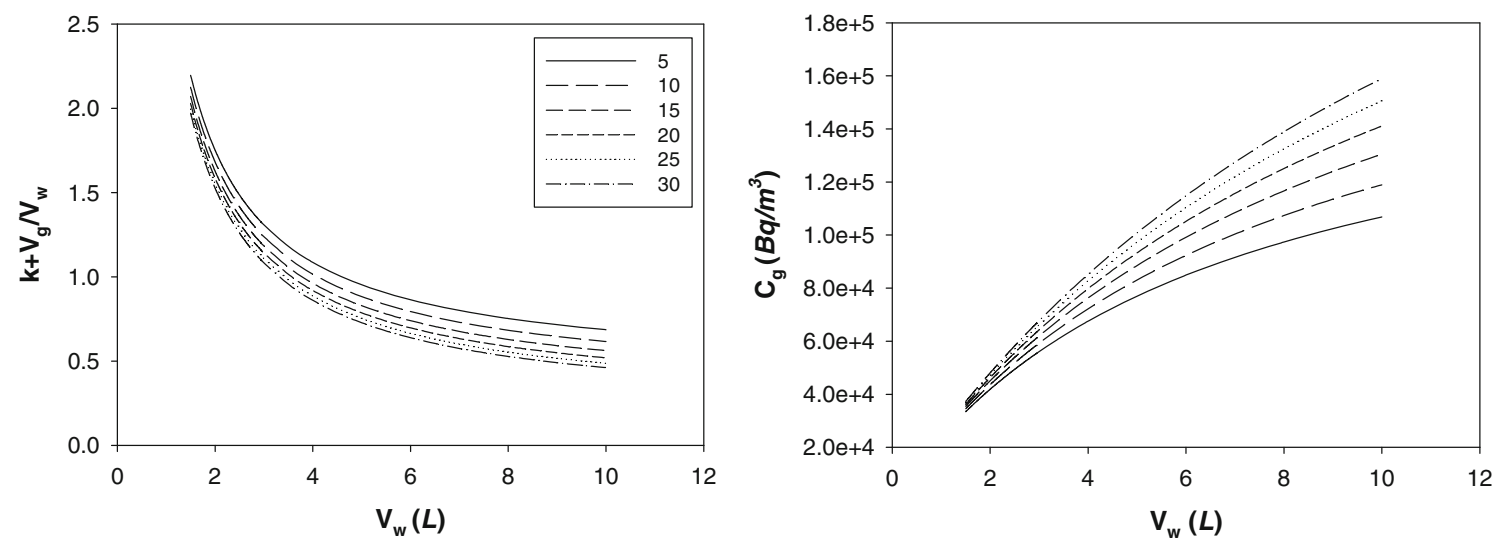

Fig. 6 Relationship of the $\mathrm{k}+\mathrm{V}_{\mathrm{g}} / \mathrm{V}_{\mathrm{w}}$ term and $\mathrm{C}_{\mathrm{g}}$ to $\mathrm{V}_{\mathrm{w}}$ in the determination of radon activity $\left(\mathrm{C}_{\mathrm{ws}}\right)$ in water samples in the temperature range of $5-30{ }^{\circ} \mathrm{C}$. $\mathrm{k}$ is the radon partition coefficient, $\mathrm{V}_{\mathrm{g}}$ and $\mathrm{V}_{\mathrm{w}}$ represent the total volumes of air and water, and $\mathrm{C}_{\mathrm{g}}$ is radon activity in air loops 
Acknowledgments Derek Lane-Smith made some very helpful suggestions on an earlier draft of this manuscript. This research was supported by a grant for basic research from the Korea Institute of Geosciences and Mineral Resources (KIGAM).

Open Access This article is distributed under the terms of the Creative Commons Attribution License which permits any use, distribution, and reproduction in any medium, provided the original author(s) and the source are credited.

\section{References}

1. NCRP (National Council on Radiation Protection and Measurements) (1984) NCRP report no. 78. NCRP, Bethesda, MD

2. Lee KY, Yoon YY, Ko KS (2010) J Radioanal Nucl Chem 286:381-385

3. Lee KY, Yoon YY, Cho SY, Ko KS, Yum B (2012) J Radioanal Nucl Chem 294:27-30
4. Burnett WC, Kim G, Lane-Smith D (2001) J Radioanal Nucl Chem 249:167-171

5. Peterson RN, Santos IR, Burnett WC (2010) Estuar Coast Shelf Sci $86: 165-178$

6. Santos IR, Lechuga-Deveze C, Peterson RN, Burnett WC (2011) Chem Geol 282:1-10

7. Durridge Co. (2001) RAD7 owner's manual 6:13

8. Schubert M, Buerkin W, Pena P, Lopez AE, Balcazar M (2006) Radiat Meas 41:492-497

9. Burnett WC, Dulaiova H (2003) J Environ Radioact 69:21-35

10. Dulaiova H, Peterson R, Burnett WC, Lane-Smith D (2005) J Radioanal Nucl Chem 263:361-365

11. Weigel F (1978) Radon Chem Zig 102:287-299

12. Clever HL (1979) Solubility data series. Pergamon Press, Oxford

13. Schubert M, Paschke A, Lieberman E, Burnett WC (2012) Environ Sci Technol 46:3905-3922

14. Xu B, Burnett WC, Lane-Smith D, Yu Z (2010) J Radioanal Nucl Chem 283:457-463 